УДК 378.147 (045)

DOI:

Вікторія Бондар, викладач кафедри дошкільної освіти Черкаського національного університету імені Богдана Хмельницького

\title{
ПІДГОТОВКА МАЙБУТНІХ УЧИТЕЛІВ ПОЧАТКОВОЇ ШКОЛИ ДО ЗДІЙСНЕННЯ ПОЗАКЛАСНОЇ РОБОТИ
}

Стаття містить теоретичне обтрунтування значущості позакласної роботи у початковій школі як структурного компоненту навчально-вихованого процесу. Проаналізовано визначення поняття "позакласна робота", окреслено специфіку підготовки майбутніх учителів початкової школи до здійснення позакласноі роботи в умовах закладу вищої освіти. Схарактеризовано критерії та показники, запропоновано до розгляду рівні сформованості готовності майбутніх учителів до здійснення позакласної діяльності у початковій школі, виокремлено етапи формування означеного феномену.

Ключові слова: позакласна робота; початкова школа; підготовка майбутніх учителів; готовність до здійснення позакласної роботи; професійна підготовка; етапи формування готовності.

Рис. 1. Табл. 1. Літ. 7.

Viktoriya Bondar, Lecturer of the Preschool Education Department, Cherkasy Bohdan Khmelnytskiy National University

\section{TRAINING OF FUTURE ELEMENTARY SCHOOL TEACHERS FOR EXTRACURRICULAR WORK}

The article analyzes the scientific approaches to the organization of extracurricular work, identifies modern interpretations of the concept of extracurricular work and determines its place in the pedagogical process of elementary school. We propose to consider the extracurricular work of teachers in elementary school as a component of pedagogical activity, which is realized through the use of different forms and types of extracurricular work according to the purpose, content, teaching methods, student audience in order to form and educate the personality of the student.

The article outlines the process of training future teachers for extracurricular work in elementary school. We explain it as a complex multifunctional process aimed at identifying the cognitive needs and motives of elementary school children, mastering them with relevant knowledge and skills in the process of implementing extracurricular work. As a result of the process of training the future teacher for extracurricular work in elementary school, we consider his / her readiness to organize the specified activity. We consider the future teacher's readiness for extracurricular work as a professionally significant quality of personality, the structure of which contains the following components: motivational-value, cognitive, operational and activity-behavioral. The publication contains information about criteria, indicators and levels of the future teacher's readiness for extracurricular work. On the basis of system, competence and activity approaches four training stages of future teachers for extracurricular work in elementary school are distinguished: content-value, reflexive-modeling, operational-activity and diagnostic. The article describes in detail the content and tasks of each stage, as well as summarizes the factors that influence the effectiveness of extracurricular work in elementary school. In particular, the relevance of isolation and introduction of pedagogical conditions aimed at influencing the formation of the future teachers' readiness for extracurricular work in elementary school is substantiated.

Keywords: extracurricular work; elementary school; preparation of future teachers; readiness for extracurricular work; vocational training; stages of formation of readiness.

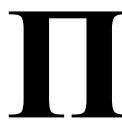

остановка проблеми у загальному вигляді та її зв'язок $з$ важливим науковими чи практичними завданнями. Оновлення змісту і технологій навчання закликає загальноосвітню школу забезпечити реалізацію найбільш актуальних і перспективних освітніх потреб особистості, суспільства і держави загалом. Розвиток громадянської самосвідомості, відродження національного виховання, формування i збереження здоров'я, розвиток цілісної і гармонійної особистості - визнано пріоритетним напрямом вдосконалення національної системи освіти. Одним із імовірних шляхів ефективного розв'язання поставлених завдань виступає ретельна організація позакласної роботи в початковій ланці, оскільки саме тут вибудовуються засади для подальшого особистісного розвитку школярів, формується їх система мотивації до учіння, від якої залежить якість навчання в школі, а, отже, особливої актуальності набуває і підготовка майбутніх учителів початкової школи до здійснення позакласної роботи в умовах закладу вищої освіти. 


\section{ПШДГОТОВКА МАЙБУТНІХ УЧИТЕЛІВ ПОЧАТКОВОӤ ШКОЛИ ДОЗДІЙСНЕННЯ ПОЗАКЛАСНОЇ РОБОТИ}

Аналіз останніх досліджень і публікацій. Особливості організації позакласної роботи у сучасній початковій школі досліджувалась у різних напрямах, а саме: позакласна робота в системі діяльності школи (М. Красовицький, С. Мартиненко, А. Сидорків та ін.); психологічні засади організації позакласної роботи в сучасній школі (І. Бех, А. Гречишкіна, О. Крутенький, Л. Соколова та ін.); питання змісту і напрямів позакласної роботи (В. Вербицький, І. Казанжи, Л. Канішевська, В. Рибалка, Д. Федоренко та ін.). Попри значну кількість наукових розвідок, питання підготовки майбутніх учителів початкової школи до позакласної роботи залишається відкритим, потребує побудови етапності зазначеного процесу, яка фактично відсутня у практиці закладів вищої освіти.

Формування мети статті. Мета статті окреслити специфіку підготовки майбутніх учителів початкової школи до здійснення позакласної роботи в умовах закладу вищої освіти й охарактеризувати ймовірні етапи означеного процесу.

Виклад основного матеріалу дослідження. Позакласна робота - це логічне і послідовне продовження цілісного навчально-виховного процесу у загальноосвітній школі. Енциклопедичні відомості визначають позакласну роботу як “складову частину” навчально-виховної роботи, що здійснюється педагогічним колективом 3 учнем чи групою учнів в позаурочний час з метою вдосконалення їх знань, умінь, навичок, індивідуальних схильностей і здібностей, а також для забезпечення розумного відпочинку i задоволення інтересів [2, 684]. Нам імпонує визначення М. Фіцули, яке пояснює позакласну роботу як різноманітну освітню і виховну роботу, що спрямована на задоволення інтересів і запитів дітей, яку організовує з учнями в позаурочнии час педагогічний колектив школи [7, 36]. На думку вченого, першочерговою метою позакласної діяльності виступає збагачення, поглиблення та закріплення знань, набутих під час навчання, формування навичок їх застосування на практиці; розширення загального і наукового світогляду учнів; вироблення вмінь і навичок, формування мотивації до самоосвіти; розбудова зацікавленості гуманітарними, природничими і технічними науками, мистецтвом, спортом; виявлення і розвиток індивідуальних здібностей тощо $[5,54]$.

Враховуючи зазначене вище, доцільно розглядати позакласну роботу як цілеспрямовану взаємодію учителя початкової школи й учнів, що має на меті формування, закріплення і поглиблення знань, оволодіння під час освітнього процесу практичними вміннями і навичками, виявлення здібностей і задатків, виховання ключових особистісних якостей (гуманність, дисциплінованість, цілеспрямованість тощо). Аналіз позакласної роботи в початковій школі дозволяє науковцям визначити їі ключові функції: навчальну, розвивальну і виховну $[5,52]$.

Позакласну роботу вчителів у початковій школі пропонуємо розглядати як складову педагогічної діяльності, що реалізується завдяки використанню різних форм і видів позакласної роботи відповідно до мети, змісту, методів навчання, учнівської аудиторії з метою формування і виховання особистості учня.

Процес підготовки майбутніх учителів до організації позакласної роботи має бути цілісним, поступовим і продуктивним. У його підвалини закладаємо сучасні підходи науковців, методистів, учителів-практиків, психологів і розглядаємо його як складний багатофункціональний процес, що спрямований на виявлення пізнавальних потреб і мотивів дітей початкової школи, оволодіння ними відповідними знаннями, вміннями і навичками у процесі імплементації позакласної роботи $[6,16]$. Результатом процесу підготовки майбутнього вчителя до позакласної роботи в початковій школі виступає його готовність до організації зазначеної діяльності. Вивчення психолого-педагогічних наукових джерел щодо готовності майбутнього вчителя до позакласної діяльності дозволяє вважати означений феномен як одну з професійно значущих якостей особистості, що уособлюється чотирма ключовими компонентами: мотиваційноціннісним, когнітивним, операційним і діяльнісноповедінковим.

Діагностика готовності майбутніх учителів до позакласної роботи в початковій школі, відповідно до вищезгаданих компонентів, здійснюється на основі наступних критеріїв і показників: рівень сформованості системи професійних мотивів (для яких значущим є рівень професійної самореалізації, стійкість професійних інтересів, наявність цільових установок і персональної відповідальності); рівень знань із циклу предметів початкової школи (якість знань, їх широта i усвідомленість); рівень розвитку практичних навичок і вмінь здійснювати позакласну роботу в початковій школі (репродуктивний, продуктивний, творчий); рівень розвитку аналітичних і прогностичних здібностей. Виокремлення зазначених критеріїв уможливило їх розподіл за рівнем сформованості: низький, достатній i високий.

Застосовуючи провідні концепції системного, компетентнісного і діяльнісного підходів, 


\section{ПЦДГОТОВКА МАЙБУТНІХ УЧИТЕЛІВ ПОЧАТКОВОЇ ШКОЛИ ДОЗДІЙСНЕННЯ ПОЗАКЛАСНОЇ РОБОТИ}

підготовку майбутніх учителів до позакласної роботи в початковій школі пропонуємо реалізовувати в процесі чотирьох етапів (Рис. 1). забезпечить можливість практичного відпрацювання прийомів і технологій позакласної роботи. Особливої актуальності на рефлексивно-моделювальному

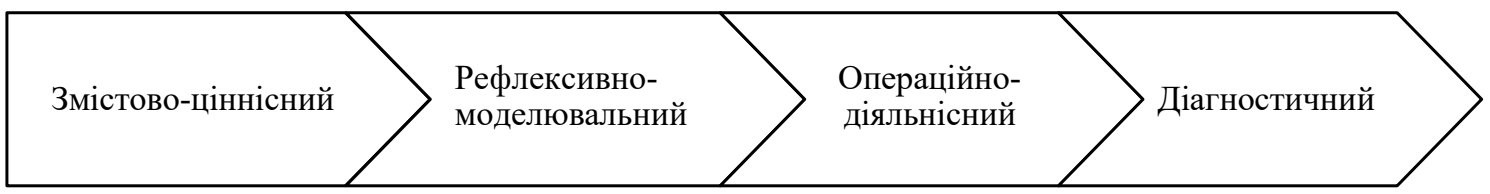

Рис. 1. Етапи підготовки майбутніх учителів до здійснення позакласної роботи

Змістово-ціннісний етап покликаний забезпечити належний рівень знань майбутнього вчителя і сформувати його мотиваційно-ціннісну систему, спрямовану на професійну діяльність здійснення позакласної роботи зокрема. В структуру зазначеного етапу можуть бути включені нормативні дисципліни циклу професійної підготовки, які передбачають змістову і методичну підготовку студентів. Навчальна діяльність на цьому етапі реалізується традиційними формами навчання (лекції, практичні, лабораторні, семінарські заняття) і за допомогою класичних методів, прийомів і технологій. Особливої уваги заслуговує процес вивчення студентами методик навчання, що мають сприяти опануванню знань, вмінь і навичок, необхідних не лише для класної, а й позакласної роботи [1, 466]. Матеріал рекомендовано пропонувати до вивчення у вигляді методичних доробків, що містять теоретичні відомості й практичні завдання, спрямовані на підготовку майбутнього учителя до позакласної роботи у початковій школі. Завдяки цьому майбутніми фахівцями з'ясовуються цілі та завдання позакласної роботи, види, форми, принципи й методики іiі реалізації. Значущим надбанням означеного етапу виступає вміння майбутніх фахівців обирати доцільні методи, засоби й прийоми активізації інтелектуальної, навчальної і пізнавальної діяльності школярів початкової ланки; здійснювати добір методичних і дидактичних матеріалів для організації позакласної роботи; критично оцінювати й аналізувати педагогічні ситуації, креативно їх розв'язувати.

На рефлексивно-моделювальному етапі відбувається зміцнення засвоєних знань студентів, набуваються практичні уміння моделювати такі педагогічні ситуації, які можуть мати місце в процесі позакласної роботи, розвиваються рефлексивні навички, поглиблюється інтерес до майбутньої професійної діяльності. Означений етап може містити спецкурс, запропонований до вивчення студентів у складі вибіркових компонентів освітньої програми, що етапі набуває педагогічне моделювання, психологічна підготовка до виконання професійних обов'язків, розв'язання індивідуальних завдань, спрямованих на формування навичок рефлексивного аналізу, організацію ефективного спілкування, створення сприятливого психологічного клімату в учнівському колективі [4, 282]. На цьому етапі підготовки майбутніх учителів до здійснення позакласної роботи у початковій школі важливо сформувати здатність у студентів визначати чинники, які впливають на їі ефективність та оперувати ними. Серед таких чинників науковець Н. Карапузова вирізняє наступні, наведені у таблиці $1[5,55]$.

Інтеграція навчальної, наукової і дослідницької діяльності здійснюється на операційнодіяльнісному етапі, що покликаний забезпечити оволодіння студентами технологією позакласної роботи на практичному рівні. Тут розвивається критичне і творче мислення майбутнього педагога, вибудовуються засади професійної діяльності, формуються навички наукового і дослідницького підходу до організації позакласної роботи. Педагогічна практика дозволяє занурити студентів у реальні педагогічні ситуації і впровадити операційно-діяльнісний етап під час самостійного виконання майбутніми вчителями наукових проектів і під час їх дослідницької діяльності. Методичне забезпечення операційнодіяльнісного етапу потребує грунтовної розробки, включаючи індивідуальні науково-дослідні проекти, завдання для самостійної роботи, комплекси додаткових завдань 3 педагогічної практики відповідно до особливостей реалізації позакласної роботи, адаптації тем курсових/ кваліфікаційних робіт (проектів) тощо [3, 238]. Особливе значення для наукової складової процесу підготовки майбутніх учителів до позакласної роботи відіграє їх залучення до роботи науковометодичних, науково-практичних конференцій, семінарів, круглих столів і наукових дискусій.

Підсумковим етапом підготовки майбутніх учителів до позакласної роботи у початковій школі $\epsilon$ діагностичний, який має на меті формування 


\section{ПЦДГОТОВКА МАЙБУТНІХ УЧИТЕЛІВ ПОЧАТКОВОЇ ШКОЛИ ДОЗДІЙСНЕННЯ ПОЗАКЛАСНОЇ РОБОТИ}

\begin{tabular}{|c|c|c|}
\hline \multicolumn{3}{|c|}{ Чинники, що впливають на ефективність позакласної роботи в початковій школі } \\
\hline \multicolumn{3}{|c|}{ Класифікація чинників } \\
\hline $\begin{array}{l}\text { Упровадження особистісно } \\
\text { орієнтованого та } \\
\text { компетентнісного підходів, що } \\
\text { передбачають спрямованість } \\
\text { навчально-виховного процесу на } \\
\text { розвиток інтересу молодших } \\
\text { школярів до вивчення } \\
\text { навчальних предметів, творчого } \\
\text { підходу та емоційно-ціннісного } \\
\text { ставлення до виконання } \\
\text { навчальних завдань. }\end{array}$ & $\begin{array}{l}\text { Реалізація принципів } \\
\text { добровільності, врахування } \\
\text { індивідуальних та вікових } \\
\text { особливостей учнів, що } \\
\text { полягають у добровільній участі } \\
\text { школярів у різних видах } \\
\text { позакласної діяльності } \\
\text { відповідно до своїх інтересів, } \\
\text { уподобань, нахилів. }\end{array}$ & $\begin{array}{l}\text { Застосування ігрових методів і } \\
\text { прийомів активізації навчально- } \\
\text { пізнавальної діяльності учнів } \\
\text { (дидактичні ігри, задачі-жарти, } \\
\text { задачі-казки, рухливі ігри, гра } \\
\text { “Брейн-ринг”, вікторини- } \\
\text { блискавки тощо), що сприяє } \\
\text { розвитку творчих здібностей } \\
\text { учнів, самостійності у пошуках } \\
\text { способів виконання завдань, } \\
\text { інтересу до навчання. }\end{array}$ \\
\hline
\end{tabular}

навичок студентів аналізу рівня пізнавальної активності учнів і самоаналізу результатів власної діяльності. Для зосередження уваги студентів на специфіці організації позакласної роботи доречною $€$ розробка відповідного навчально-методичного забезпечення у формі навчальних посібників, методичних рекомендацій, спецкурсів тощо.

Висновки 3 даного дослідження i перспективи подальших розвідок у даному напрямку. Таким чином, подібна організація професійної підготовки не лише сприяє оволодінню майбутніми вчителями базовими компетентностями, що дозволяють організовувати позакласну роботу в початковій школі, а й створює певний резерв професійного досвіду на майбутне, тим самим розширюючи можливості фахівця і забезпечуючи його конкурентоспроможність. Зміст статті не вичерпує всіх аспектів досліджуваної проблематики i потребує подальшого теоретичного й експериментального дослідження, зокрема, виокремлення i впровадження педагогічних умов, покликаних впливати на формування готовності майбутніх учителів до здійснення позакласної роботи в початковій школі.

\section{ЛІТЕРАТУРА}

1. Боднар К. С. Организация внеклассной работы по английскому языку у младших школьников с учетом учебных интересов учащихся при изучении язика. Молодой ученый. 2018. № 21. С. 465-467.

2. Енциклопедія освіти / гол. ред. В.Г. Кремень. Київ, 2008. 1040 с.

3. Казанжи I. В. Створення виховуючого середовища у вищому педагогічному навчальному закладі як засіб підготовки майбутніх фахівців до здійснення виховної діяльності. Вісник Житомирського педагогічного університету. Вип. № 6. Житомир, 2000. С.237-240.

4. Казанжи I. В. Теоретична і практична підготовка студентів до позакласної виховної роботи у початковій школі // Теоретико-методичні проблеми виховання дітей та учнівської молоді: Зб. наук. пр. у 2-х частинах. Кн. 2. Київ, 1999. С. 281289.

5. Карапузова Н. Д. Підготовка майбутніх учителів початкових класів до позакласної роботи 3 математики. Молодь і ринок. Вип. №11(118). Дрогобич: ДДПУ ім. І. Франка, 2014. С. 52-57.

6. Навчальні програми для загальноосвітніх навчальних закладів із навчання українською мовою. 1-4 класи. Київ: Видавничий дім “Освіта”, $2012.392 \mathrm{c}$.

7. Фіцула М. М. Педагогіка: Навчальний посібник для студ. вищих педагогічних закладів освіти. Тернопіль: ТДПУ, 1997. 192 с.

\section{REFERENCES}

1. Bodnar, K. S. (2018). Organizatsiya vneklassnoy raboty po angliyskomu yazyku u mladshikh shkolnikov s uchetom uchebnykh interesov uchashchikhsya pri izuchenii yazyka [Organization of extracurricular work in the English language in primary school students, taking into account the educational interests of students in language learning]. Young scientist. Vol. 21, pp. 465-467. [in Russian].

2. Kremen, V.G. (2008). Entsyklopediia osvity [Encyclopedia of Education]. Kyiv, Yurincom Inter, 1040 p. [in Ukrainian].

3. Kazanzhi, I. V. (2000). Stvorennia vykhovuiuchoho seredovyshcha u vyshchomu pedahohichnomu navchalnomu zakladi yak zasib pidhotovky maibutnikh fakhivtsiv do zdiisnennia vykhovnoi diialnosti [Creating an educational environment in a higher educational institution as a means of preparing future specialists for educational activities]. Zhytomyr. Vol. 6, pp. 237-240. [in Ukrainian].

4. Kazanzhi, I. V. (1999). Teoretychna $i$ praktychna pidhotovka studentiv do pozaklasnoi vykhovnoi roboty u pochatkovii shkoli [Theoretical 
and practical preparation of students for extracurricular education in elementary school]. Theoretical and Methodological Problems of Parenting and Student Youth: ACollection of Scientific Papers in 2 Parts. Kyiv. Vol. 2, pp. 281-289. [in Ukrainian].

5. Karapuzova, N. D. (2014). Pidhotovka maibutnikh uchyteliv pochatkovykh klasiv do pozaklasnoi roboty z matematyky [Preparing future elementary school teachers for extracurricular math work]. Youth and market. Drohobych. Vol. 11(118), pp.52-57. [in Ukrainian].
6. Navchalni prohramy dlia zahalnoosvitnikh navchalnykh zakladiv iz navchannia ukrainskoiu movoiu. 1-4 klasy (2012). [Curricula for comprehensive educational institutions in the Ukrainian language. Grades 14]. Kyiv, Education House Publishing House. 392 p. [in Ukrainian].

7. Ficula, M. M. (1997). Pedahohika: Navchalnyy posibnyk dlia stud. vyshchykh pedahohichnykh zakladiv osvity [Pedagogy: A textbook for students. higher educational institutions of education]. Ternopil. 192 p. [in Ukrainian].

Стаття надійшла до редакції 30.09.2019

\section{УДК 61.007.2:378.147(045)}

DOI:

Аліна Стонога, асистент кафедри педагогіки, методики та менеджменту освіти Украӥнської інженерно-педагогічної академї

\section{СТРУКТУРА ГОТОВНОСТІ МАЙБУТНІХ ІНЖЕНЕРІВ-ПЕДАГОГІВ ДО ПРОФЕСІЙНОЇ КОМУНІКАЦІї}

У статті на основі аналізу науково-педагогічної літератури розглянута сутність поняття “готовність”. Охарактеризовано компоненти готовності майбутніх інженерів-педагогів до професійної комунікації: мотиваційно-иіннісний, когнітивний, дієвий, особистісно-розвивальний, які визначено за чітко окресленими критеріями та показниками. Обтрунтовано доцільність формування готовності майбутніх інженерів-педагогів до професійної комунікаиії в контексті фахової підготовки. Визначено суть і структуру готовності майбутніх інженерів-педагогів до професійної комунікаиії. рівні.

Ключові слова: готовність до професійної комунікаиії; структура; компоненти; критерії; показники;

Jim. 7.

Alina Stonoha, Assistant of the Pedagogy, Methods and Management of Education Department Ukrainian Engineering Pedagogic Academy

\section{THE STRUCTURE OF READINESS OF FUTURE ENGINEER-PEDAGOGUES FOR THE PROFESSIONAL COMMUNICATION}

In the article on the basis of the analysis of scientific and pedagogical literature the essence of the concept "readiness" is considered.

The analysis of the psychological and pedagogical literature showed that the problem of professional readiness is considered by scientists on the personal and active levels: on the personal level, professional readiness is considered as a process of forming the professional qualities of personality, at the actual level, professional readiness is considered as the result of professional training, professional competence is formed.

The components of the readiness of future engineers-pedagogues for professional communication are characterized: motivational-value, cognitive, effective, personal-developmental, which are defined by clearly defined criteria and indicators.

The expediency of formation of the readiness of future engineers-pedagogues to professional communication in the context of professional training is substantiated. The essence and structure of the readiness of future engineerpedagogues to professional communication are determined. In our study, all the components of the readiness of future engineer-pedagogues for professional communication have corresponding criteria, each of which contains a set of indicators. The study of the levels of criteria and indicators formation makes it possible to find out the effectiveness of vocational-communicative preparation of students in the conditions of study in a higher education institution. Therefore, in the context of our study, four criteria were identified with corresponding metrics that fit the selected components. The criterion we have defined - motivation to master the skills and skills of professional communication and orientation to learning, corresponds to the motivational value component. It is connected with the necessity of taking into account in the process of communicative preparation of the future engineer-teacher of 